\title{
Leucocyte migration inhibition test in cases of ischaemic heart disease
}

\author{
R. K. SHARMA, R. C. AHUJA, O. P. TANDON, AND U. C. CHATURVEDI* \\ From the Department of Medicine and Department of Pathology and Bacteriology, K.G. Medical College, \\ Lucknow, India
}

SUMMARY Cases of ischaemic heart disease have been studied for the cell-mediated immune response against human heart antigen by using the leucocyte migration inhibition test. In 30 cases of acute myocardial infarction, the leucocyte migration inhibition values started increasing from the first week reaching a peak in 3 to 4 weeks and then declining but still above control values 12 months after infarction. The leucocyte migration inhibition values were significantly higher than control values in another 10 patients with late complications of previous infarction and in those patients with acute myocardial infarction who were less than 40 years of age, who had extensive anterior infarction, or who had a past history of angina pectoris. The leucocyte migration inhibition values were negligible in all the 12 patients with stable angina pectoris, but were high in 2 of the 8 with unstable angina and in 3 of the 4 with the intermediate coronary syndrome. The leucocyte migration inhibition values were much higher in patients with complications, which may be the result of cardiac damage by a cell-mediated immune response.

Humoral autoantibodies have been widely studied in ischaemic heart disease (Gery et al., 1960; Ehrenfeld et al., 1961; Van der Geld, 1964; Heine et al., 1966; Strausz and Dóbiás, 1967; Sharma et al., 1970). These antibodies are cytotoxic to myocardial cells grown in tissue culture (Lotta, 1958; Thompson and Halbert, 1971) and to myocardium on passive transfer in experimental animals (Chaturvedi and Mehrotra, 1967a). Development of anticardiac antibodies in rats was shown as long ago as 1945 by Cavelti, but cell-mediated immune response against heart has only been demonstrated recently in experimental animals (Chaturvedi and Mehrotra, 1967a, b; Chaturvedi et al., 1971b). Little work has been done on the cellular sensitisation which occurs in heart disease. Cell-mediated immune response against rat heart (Wartenberg and Brostoff, 1973) or human heart antigens (Chaturvedi et al., 1977) has been shown in cases of myocardial infarction by using the leucocyte migration inhibition test. In the present study an attempt was made to study the relation of cell-mediated immune response to various clinical presentations in cases of ischaemic heart disease.

\section{Subjects and methods}

Sixty-four patients with ischaemic heart disease

Received for publication 20 June 1977 were studied; these included 20 with angina pectoris, 4 with intermediate coronary syndrome, 30 with acute myocardial infarction seen within 1 week of onset, and 10 with old myocardial infarction (3 to 12 months after acute illness). There were 60 men and 4 women, aged 30 to 91 years (Table 1). Angina pectoris was diagnosed when a patient gave a history of ischaemic cardiac pain, usually lasting for 3 to 5 minutes and in some cases 10 to 20 minutes but never more than 30 minutes; the electrocardiograms at rest or after exercise showed evidence of myocardial ischaemia. The patients with intermediate coronary syndrome had had prolonged ischaemic cardiac pain lasting for more than 30 minutes but had no evidence of myocardial necrosis on serial 12lead electrocardiograms or aspartate aminotransferase estimations performed during the following 3 days. Acute myocardial infarction was diagnosed in those with a history of prolonged ischaemic cardiac pain; the electrocardiogram showed pathological $Q$ waves and characteristic ST segment and $T$ wave changes. The old myocardial infarction cases were those who had suffered from proven acute myocardial infarction 3 to 12 months earlier. The patients with angina pectoris were classed as stable or unstable (Desai and Alexander, 1972). Angina was regarded as stable when symptoms in a given patient were predictably produced on exertion and relieved by rest or glyeryl trinitrate or other similar drugs. These patients had had angina for 6 months 
Table 1 Age and sex distribution of the cases

\begin{tabular}{|c|c|c|c|c|c|c|c|c|c|}
\hline & \multirow{2}{*}{$\begin{array}{l}\text { Total no. of } \\
\text { cases }\end{array}$} & \multicolumn{2}{|l|}{ Sex } & \multicolumn{6}{|l|}{ Age } \\
\hline & & Males & Females & $30-40$ & $41-50$ & $51-60$ & $61-70$ & $>71$ & Mean \\
\hline \multirow{3}{*}{$\begin{array}{l}\text { Study group } \\
\text { Angina pectoris } \\
\text { Intermediate } \\
\text { coronary syndrome } \\
\text { Myocardial } \\
\text { infarction }\end{array}$} & 20 & 20 & - & 2 & 8 & 8 & 2 & - & $50 \cdot 7$ \\
\hline & 4 & 4 & - & 1 & 2 & 1 & - & - & $46 \cdot 0$ \\
\hline & 40 & 36 & 4 & 6 & 16 & 13 & 3 & 2 & 50.5 \\
\hline$\overline{\text { Total }}$ & 64 & 60 & 4 & 9 & 26 & 22 & 5 & 2 & $50 \cdot 4$ \\
\hline$\overline{\text { Control group }}$ & 20 & 18 & 2 & 5 & 8 & 5 & 1 & 1 & $48 \cdot 9$ \\
\hline
\end{tabular}

or more, more or less constant in severity for at least 1 month. Angina was said to have become unstable when there had been a change in symptom pattern; pain was more easily provoked and/or started occurring spontaneously and lasted longer, and the previously successful methods of relieving pain were no longer effective. Associated risk factors, viz. diabetes mellitus, hypertension, hyperlipidaemia, positive family history, and smoking, were identified (Table 2). Cases of myocardial infarction were differentiated into anterior (including extensive anteriorFriedman, 1971) and inferior and/or posterior myocardial infarction; a note was also made of complications and past history of angina pectoris.

The control group consisted of 20 healthy, agematched individuals who had no clinical, radiological, or electrocardiographic evidence of any heart disease.

\section{LEUCOCYTE MIGRATION INHIBITION TEST}

The heart of a 36-year-old man who died in a road accident was removed within 2 hours of death. The heart was cut in thin slices, washed with sterile phosphate buffered saline, and stored at $-20^{\circ} \mathrm{C}$. A 10 per cent heart extract was prepared in PBS and was used as antigen (Chaturvedi et al., 1973b).

In the 30 acute myocardial infarct patients, the leucocyte migration inhibition test was done on heparinised blood collected at 1, 2, 3, and 4 weeks and 3,6 , and 12 months after infarction.
The leucocytes were separated from the plasma, washed thrice with Hank's basal salt solution, and introduced into glass capillary tubes, one end of which was sealed by heat; the tubes were centrifuged at $500 \mathrm{rpm}$ for 20 minutes and then cut at the cell-fluid interphase, the portion containing cells being fixed in paraffin wax in migration chambers. The chambers were filled with medium minimum essential (Eagle's) containing 10 per cent newborn calf serum. The antigen (heart extract) was added to one set of chambers while another set remained without antigen for control. The optimum dose of antigen was determined in pilot experiments. The tests were done in triplicate both in controls and in the cases in the study group. The chambers were incubated at $37^{\circ} \mathrm{C}$ for 20 hours. The area of cell migration was drawn on Whatman No. 1 chromatographic paper with Camera Lucida using a magnification of $\times 15$. The area of migration on paper was cut and weighed on a precision balance. The results were expressed as per cent inhibition of leucocyte migration (LMI \%) in the presence of antigen, according to the following formula:

$\operatorname{LMI}(\%)=$

Migration without antigen - Migration with antigen $\times 100$.

Migration without antigen

A migration inhibition of 20 per cent or more was considered significant (Oritz-Oritz et al., 1974).

Table 2 Analysis of risk factors

\begin{tabular}{|c|c|c|c|c|c|c|c|c|c|}
\hline \multirow[t]{2}{*}{ Group } & \multirow{2}{*}{$\begin{array}{l}\text { Total no. of } \\
\text { cases }\end{array}$} & \multirow{2}{*}{$\begin{array}{l}\text { No. of cases } \\
\text { without risk } \\
\text { factors }\end{array}$} & \multirow{2}{*}{$\begin{array}{l}\text { Total no. of } \\
\text { cases with risk } \\
\text { factors }\end{array}$} & \multicolumn{6}{|c|}{ No. with various risk factors } \\
\hline & & & & $\begin{array}{l}+v e \\
\text { family } \\
\text { history }\end{array}$ & $\begin{array}{l}\text { Diabetes } \\
\text { mellitus }\end{array}$ & $\begin{array}{l}\text { Hyper- } \\
\text { tension }\end{array}$ & $\begin{array}{l}\text { Hyper- } \\
\text { lipidaemia }\end{array}$ & Obesity & Smoking \\
\hline \multirow{3}{*}{$\begin{array}{l}\text { Angina pectoris } \\
\text { Intermediate } \\
\text { coronary syndrome } \\
\text { Myocardial } \\
\text { infarction }\end{array}$} & 20 & 12 & 8 & 1 & 2 & 2 & - & 1 & 5 \\
\hline & 4 & 2 & 2 & - & 1 & - & 1 & 一 & 2 \\
\hline & 40 & 26 & 14 & 3 & 6 & 3 & 2 & 3 & 9 \\
\hline$\overline{\text { Total }}$ & 64 & 40 & 24 & 4 & 9 & 5 & 3 & 4 & 16 \\
\hline
\end{tabular}




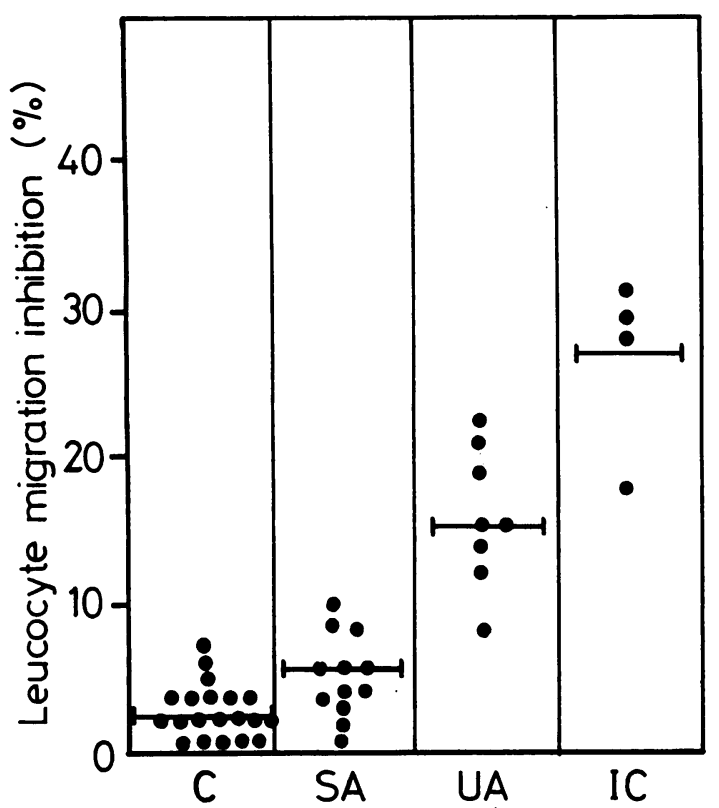

Fig. 1 Leucocyte migration inhibition in healthy controls $(C)$, cases of stable angina pectoris $(S A)$, unstable angina pectoris $(U A)$, and intermediate coronary syndrome (IC): each point represents the mean of 3 estimations.

\section{Results}

In healthy controls the mean leucocyte migration inhibition was $2 \pm 1$ per cent. There was no significant relation between leucocyte migration inhibition and age or sex in the control cases. In cases of stable angina mean leucocyte migration inhibition was $5 \pm 3$ per cent and in unstable angina $16 \pm 5$ per cent (Fig. 1). Two of the 8 cases of unstable angina had leucocyte migration inhibition values above 20 per cent ( 21 and $22 \%$ ) but the other 6 had lower values. Four cases of the intermediate coronary syndrome had leucocyte migration inhibition values of $32,29,27$, and 17 per cent, with a mean value of $26 \pm 6$ (Fig. 1).

The cases of myocardial infarction were studied in greater detail and an attempt was made to correlate the leucocyte migration inhibition values with various possibly relevant factors.

TIME AFTER MYOCARDIAL INFARCTION

The results are presented in Fig. 2. The mean leucocyte migration inhibition value was $22 \pm 8$ per cent in the first week, $50 \pm 15$ per cent in the second week, $69 \pm 8$ per cent in the third week, $70 \pm 9$ per cent in the fourth week, $55 \pm 8$ per cent in the third month, $45 \pm 14$ per cent in the sixth month, and $39 \pm$

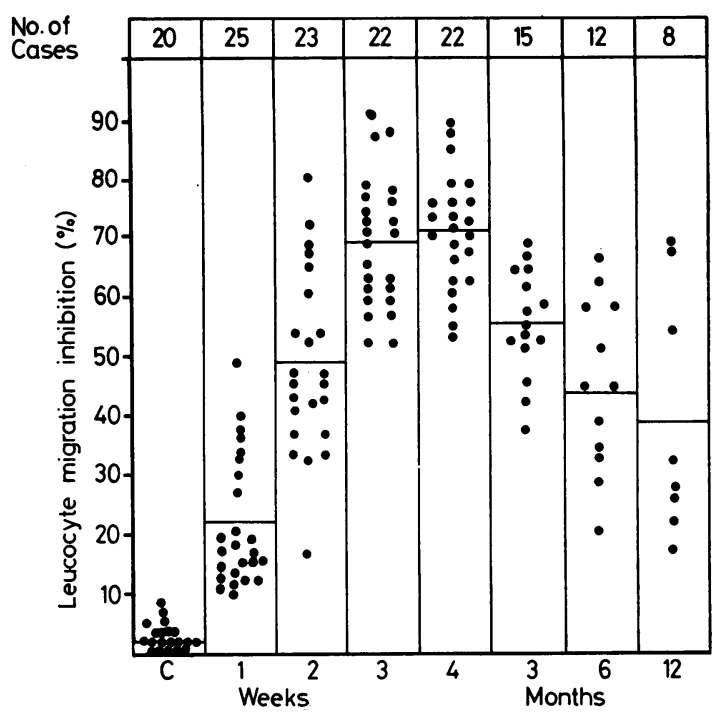

Fig. 2 Leucocyte migration inhibition in healthy controls $(C)$ and at different times after acute myocardial infarction.

20 per cent in the twelfth month. It is evident from Fig. 2 that inhibition of leucocyte migration increased during the first 3 or 4 weeks reaching a peak value at that time, then gradually declined from the third to the twelfth month after myocardial infarction.

In the following paragraphs, the peak leucocyte migration inhibition value during the initial 4-week period has been related to the various factors.

\section{AGE OF PATIENT}

There were significantly higher leucocyte migration inhibition values in patients between 30 and 40 years of age than in those over 40 years $(P<0.05)$ (Table 3).

SITE OF MYOCARDIAL INFARCTION

The relation of the site of infarction and leucocyte migration inhibition is summarised in Fig. 3. The mean leucocyte migration inhibition value was

Table 3 Relation of mean leucocyte migration inhibition (LMI) to age of patients with acute myocardial infarction

\begin{tabular}{lll}
\hline Age $(y)$ & No. of cases & Mean $L M I \pm S D$ \\
\hline $30-40$ & 5 & $77 \pm 5^{\star}$ \\
$41-50$ & 13 & $68 \pm 9$ \\
$51-60$ & 9 & $72 \pm 11$ \\
$61-70$ & 2 & 64 \\
$71-91$ & 1 & 64 \\
\hline
\end{tabular}

*Difference between mean value for patients aged 30 to 40 years significantly different from mean value for patients over 40 years $(P<0.05)$. 


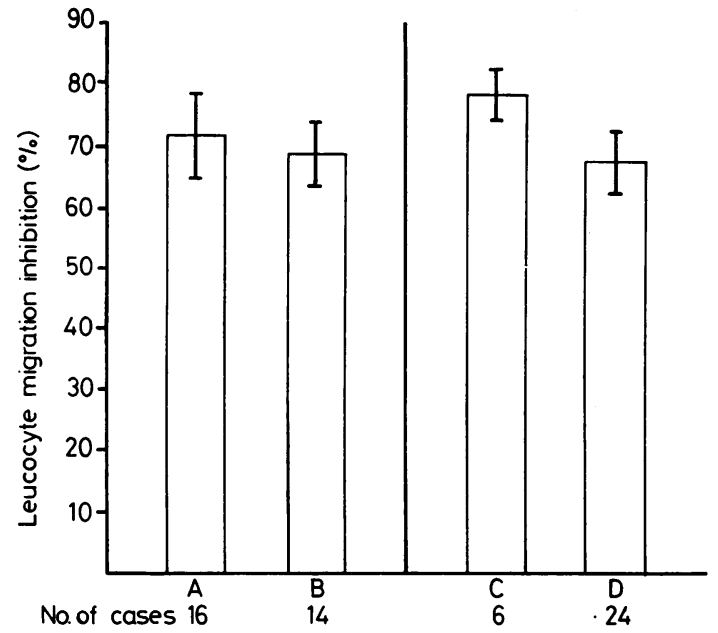

Fig. 3 Leucocyte migration inhibition in relation to site and extent of infarction. (A) Anterior infarction, (B) inferior/posterior infarction, $(C)$ extensive anterior infarction, and $(D)$ remaining anterior infarction/ inferior/posterior infarction.

$71 \pm 10$ and $70 \pm 10$ per cent in cases of anterior infarction and inferior/posterior infarction, respectively $(P>0.05)$. However, the cases of extensive anterior infarction showed $78 \pm 7$ per cent inhibition of leucocyte migration, compared with $68 \pm 10$ per cent inhibition of migration in all other infarction cases $(P<0.01)$.

\section{RISK FACTORS}

The risk factors taken into account were diabetes mellitus, hypertension, hyperlipidaemia, smoking, and positive family history. Mean leucocyte migration inhibition values in 11 cases of acute myocardial infarction with risk factors and in 19 cases without risk factors were $68 \pm 9$ and $71 \pm 10$ per cent, respectively ( $P>0.05$ ) (Fig. 4).

\section{HISTORY OF ANGINA PECTORIS}

Seven patients had had angina for 6 months or more. The mean leucocyte migration inhibition value in

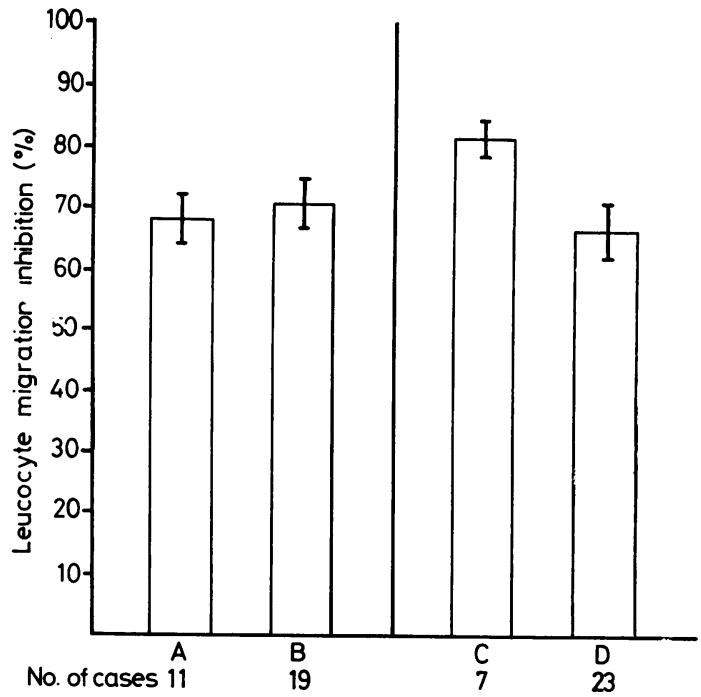

Fig. 4 Leucocyte migration inhibition in cases of acute myocardial infarction, $(A)$ with risk factors, $(B)$ without risk factors, $(C)$ with past history of angina pectoris, and (D) without past history of angina pectoris.

such patients was $82 \pm 8$ per cent, while in another 23 patients who never had angina it was $67 \pm 8$ per cent (Fig. 4). The difference between these two groups is significant $(P<0.001)$.

\section{COMPLICATIONS}

Twelve patients with acute myocardial infarction had various complications (arrhythmias, left ventricular failure, congestive heart failure, or pericarditis). The mean leucocyte migration inhibition value in such patients was $67 \pm 9$ per cent (Table 4) and in the 18 cases with no complications the mean leucocyte migration inhibition value was $72 \pm 10$ per cent $(P>0.05)$. Myocardial infarct patients who were readmitted with angina, congestive heart failure, left ventricular failure, the shoulder hand syndrome, or Dressler's syndrome, 3 or 12 months after the initial illness, had mean leucocyte migration inhibition values significantly higher than those in uncomplicated cases (Table 4).

Table 4 Relation of leucocyte migration inhibition (LMI) to complications of myocardial infarction

\begin{tabular}{|c|c|c|c|c|c|c|c|c|}
\hline & \multicolumn{2}{|c|}{ Acute infarction } & \multicolumn{6}{|c|}{ Old myocardial infarction ${ }^{\star}$} \\
\hline & \multirow[t]{2}{*}{ No. of cases } & \multirow{2}{*}{$L M I \pm S D$} & \multicolumn{2}{|l|}{3 months } & \multicolumn{2}{|l|}{6 months } & \multicolumn{2}{|l|}{12 months } \\
\hline & & & No. of cases & $L M I \pm S D$ & No. of cases & $L M I \pm S D$ & No. of cases & $L M I \pm S D$ \\
\hline $\begin{array}{l}\text { Uncomplicated } \\
\text { Complicated } \\
\end{array}$ & $\begin{array}{l}18 \\
12 \\
\end{array}$ & $\begin{array}{l}72 \pm 10 \\
67 \pm 9 \\
\end{array}$ & $\begin{array}{r}11 \\
4 \\
\end{array}$ & $\begin{array}{l}52 \pm 7 \\
64 \pm 4 \\
\end{array}$ & $\begin{array}{l}8 \\
4 \\
\end{array}$ & $\begin{array}{l}35 \pm 14 \\
61 \pm 3 \\
\end{array}$ & $\begin{array}{l}5 \\
3 \\
\end{array}$ & $\begin{array}{l}25 \pm 6 \\
64 \pm 6 \\
\end{array}$ \\
\hline $\bar{P}$ value & & $>0.05$ & & $<0.05$ & & $<0.001$ & & $<0.001$ \\
\hline
\end{tabular}

*This group includes patients originally seen as cases of acute myocardial infarction who had late complications, as well as those seen for the first time 3 to 12 months after their acute myocardial infarct. 


\section{Discussion}

In the present study, myocardial infarct patients showed significant leucocyte migration inhibition which increased to a peak value 3 or 4 weeks after infarction and then declined, but which could still be shown after 12 months. Similarly, titres of humoral anticardiac antibodies are greatest 3 weeks after myocardial infarction (Sharma et al., 1970). Also, in serial experimental studies peak values of humoral antibodies and cell mediated immune response were found 3 to 4 weeks after pericardiotomy (Chaturvedi et al., 1973a). Wartenberg and Brostoff (1973) found significant leucocyte migration inhibition in all the 14 patients studied within 2 weeks and in 2 cases studied 3 to 4 weeks after myocardial infarction; their failure to show a correlation between leucocyte migration inhibition and time after infarction may be the result of the smaller number of patients and fewer observations on each patient.

The patients with stable angina pectoris showed insignificant leucocyte migration inhibition $(5 \pm$ $3 \%)$. Two of the 8 patients with unstable angina pectoris had more than 20 per cent leucocyte migration inhibition ( 21 and $22 \%$ ). Wartenberg and Brostoff (1973) studied 2 cases of angina pectoris and found significant inhibition of leucocyte migration. Of 4 patients with the intermediate coronary syndrome, 3 showed significant leucocyte migration inhibition (mean $26 \pm 6 \%$ ). Humoral antibodies have been found in 42 to 63 per cent of cases with angina pectoris (Davies and Gery, 1960; Heine et al., 1966; Strausz and Dóbiás, 1967; Das et al., 1974). These observations indicate release of cardiac antigens in such patients, which may be the result of necrosis of myocardial fibres (Hurst et al., 1974).

Significantly higher leucocyte migration inhibition values were found in patients below the age of $\mathbf{4 0}$ years, with extensive anterior infarction, past history of angina pectoris, or late complications of infarction. The presence of coronary risk factors or complications of acute myocardial infarction did not affect the leucocyte migration inhibition values.

It was interesting to find that there were significantly higher leucocyte migration inhibition values in 11 myocardial infarct patients with late complications, including 3 with postinfarction angina, and 1 each of Dressler's syndrome and the shoulder hand syndrome. These higher leucocyte migration inhibition values may be the result of increased and/ or recurrent release of cardiac antigens and consequent great sensitisation of T-cells. On the other hand, the sensitised T-cells may be damaging the heart thus causing these manifestations. The higher leucocyte migration inhibition values may reflect greater T-cell activity. There is evidence that antibodies are produced as a result of cardiac injury (Chaturvedi, 1974). Antibodies may thus be produced as a result of myocardial infarction. Since anticardiac antibodies (both humoral and cellular) have been shown to produce cardiac damage on passive transfer to normal animals (Chaturvedi and Mehrotra, 1967a), it is likely that the abovementioned complications may be caused by these antibodies.

It is interesting to speculate on why complications occur in some cases and not in others. This may depend upon certain factors which may potentiate cardiotoxic effects of antibodies: two of these have been reported in experimental studies, isoprenaline (Chaturvedi and Mehrotra, 1969), and Coxsackie B4 infection (Chaturvedi et al., 1971a), but it is not known how far these experimental observations can be extrapolated to human patients.

Bauer et al. (1972) found no difference in anticardiac antibody titres in complicated compared with uncomplicated cases of myocardial infarction. There was no relation between antibody titre and the occurrence of the post-cardiotomy syndrome (to be published). It may, therefore, be that the cell-mediated immune response is more important as a cause of cardiac damage; this view is supported by observations in experimental animals (Natu and Chaturvedi, 1977).

We are grateful to Dr R. M. L. Mehrotra for constant help and encouragement, and to $\mathrm{Mr}$ S. M. Natu and MrV.S. Negi for technical assistance. The study was carried out with financial assistance from the Medical Research Centre, Bombay Hospital Trust, Bombay.

\section{References}

Bauer, H., Waters, J. T., and Talano, J. V. (1972). Antimyocardial antibodies in patients with coronary artery disease. American Heart fournal, 83, 612-619.

Cavelti, P. A. (1945). Auto-antibodies in rheumatic fever. Proceedings of the Society for Experimental Biology and Medicine, 60, 379-381.

Chaturvedi, U. C. (1974). Editorial-Role of autoimmunity in cardiac diseases. Indian fournal of Pathology and Bacteriology, 17, 199-204.

Chaturvedi, U. C., Davies, J. W., and Flewett, T. H. (1973b). Separation and characterization of cardiac antigen proteins. Clinical and Experimental Immunology, 15, 613-622.

Chaturvedi, U. C., Gupta, R. K., Kapoor, A. K., Mathur, A., and Mehrotra, R. M. L. (1971a). Effect of viral infection on immunological cardiac injury in rats. Indian fournal of Medical Research, 59, 1-4.

Chaturvedi, U. C., Gupta, R. K., and Mehrotra, R. M. L. (1971b). Antigenicity and immunopathogenicity of the chemical fractions of heart. Indian fournal of Medical Research, 59, 1237-1244. 
Chaturvedi, U. C., Mathur, A., Gupta, R. K., and Mehrotra, R. M. L. (1973a). Immunopathological studies in pericardiotomised rats. Fournal of Pathology, 109, 345-350.

Chaturvedi, U. C., and Mehrotra, R. M. L. (1967a). Expermentally produced immunological cardiac lesions. Indian fournal of Medical Research, 55, 21-28.

Chaturvedi, U. C., and Mehrotra, R. M. L. (1967b). Effect of neonatal thymectomy on experimentally produced immunological cardiac lesions. Nature (London), 216, 267-268.

Chaturvedi, U. C., and Mehrotra, R. M. L. (1969). Effect of isoprenaline on experimentally produced immunologic cardiac lesions. Indian fournal of Medical Sciences, 23, 8387.

Chaturvedi, U. C., Sharma, R. K., Mathur, A., and Ahuja, R. C. (1977). Migration of inhibition test on leucocytes from patients of myocardial infarction. Indian fournal of Pathology and Microbiology, 20, 197-200.

Das, S. K. T., Cassidy, J. T., and Petty, R. E. (1974). The significance of heart reactive antibodies in heart disease. Chest, 66, 179-181.

Davies, A. M., and Gery, I. (1960). Role of autoantibodies in heart disease. American Heart fournal, 60, 669-674.

Desai, D. C., and Alexander, S. (1972). Treatment of severe angina pectoris. Medical Clinics of North America, 56, 599609.

Ehrenfeld, E. N., Gery, I., and Davies, A. M. (1961). Specific antibodies in heart disease. Lancet, 1, 1138-1141.

Friedman, H. H. (1971). Diagnostic Electrocardiography and Vector Cardiography, 6th ed. McGraw-Hill, New York.

Gery, I., Davies, A. M., and Ehrenfeld, E. N. (1960). Heart specific autoantibodies. Lancet, 1, 471-472.

Heine, W. I., Friedman, H., Mandell, M. S., and Goldberg, H. (1966). Antibodies to cardiac tissue in acute ischaemic heart disease. American fournal of Cardiology, 17, 798-803.

Hurst, J. W., Logue, R. B., Schlant, R. C., and Wegner, N. K. (1974). (Eds.) The Heart, Arteries and Veins, 3rd ed., pp. 985 and 1039. McGraw-Hill, New York.

Lotta, H. (1958). Anti-heart serum and reactivity of different cell types in tissue culture. Proceedings of the Society for Experimental Biology and Medicine, 90, 392-394.

Natu, S. M., and Chaturvedi, U. C. (1977). Immunopathogenicity of the purified cardiac protein antigens. Indian Fournal of Medical Research, 65, 554-562.

Oritz-Oritz, L., Zamacona, G., Garmilla, C., and Arellano, M. T. (1974). Migration inhibition test in leucocytes from patients allergic to penicillin. fournal of Immunology, 113, 993-997.

Sharma, S. S., Kumar, S., Kunwar, K. B., Mehrotra, R. M. L., Chaturvedi, U. C., and Mitra, M. K. (1970). Anticardiac antibodies in ischaemic heart disease. Fournal of the Association of Physicians of India, 18, 595-604.

Strausz, I., and Dóbiás, Gy. (1967). Autoantibodies reacting with heart muscle tissue in coronary heart disease. Fournal of Clinical Pathology, 20, 161-165.

Thompson, A., and Halbert, S. P. (1971). The cardiac immune system. III. Studies on the cytotoxicity of heart antibodies for pulsating rabbit and rat heart cells in tissue culture. International Archives of Allergy and Applied Immunology, 40, 274-286.

Van der Geld, H. (1964). Anti-heart and antiboaies in the postpericardiotomy and postmyocardial-infarction syndromes. Lancet, 2, 617-618.

Wartenberg, J.r, and Brostoff, J. (1973). Leucocyte migration inhibition by heart extract and liver mitochondria in patients with myocardial infarction. British Heart fournal, 35, 845-848.

Requests for reprints to Dr U. C. Chaturvedi, Department of Pathology and Bacteriology, K.G. Medical College, Lucknow, 226003, India. 